\title{
High-throughput detection of aberrant imprint methylation in the ovarian cancer by the bisulphite PCR-Luminex method
}

Hitoshi Hiura ${ }^{1}$, Hiroaki Okae ${ }^{1}$, Hisato Kobayash², Naoko Miyauchi ${ }^{1}$, Fumi Sato ${ }^{1}$, Akiko Sato ${ }^{3}$, Fumihiko Suzuki ${ }^{3}$, Satoru Nagase ${ }^{3}$, Junichi Sugawara ${ }^{3}$, Kunihiko Nakai ${ }^{4}$,Nobuo Yaegashi ${ }^{3}$ and Takahiro Arima ${ }^{1^{*}}$

\begin{abstract}
Background: Aberrant DNA methylation leads to loss of heterozygosity $(\mathrm{LOH})$ or loss of imprinting (LOI) as the first hit during human carcinogenesis. Recently we developed a new high-throughput, high-resolution DNA methylation analysis method, bisulphite PCR-Luminex (BPL), using sperm DNA and demonstrated the effectiveness of this novel approach in rapidly identifying methylation errors.

Results: In the current study, we applied the BPL method to the analysis of DNA methylation for identification of prognostic panels of DNA methylation cancer biomarkers of imprinted genes. We found that the BPL method precisely quantified the methylation status of specific DNA regions in somatic cells. We found a higher frequency of LOI than LOH. LOI at IGF2, PEGI and H19 were frequent alterations, with a tendency to show a more hypermethylated state. We detected changes in DNA methylation as an early event in ovarian cancer. The degree of LOI (LOH) was associated with altered DNA methylation at IGF2/H19 and PEG1.

Conclusions: The relative ease of BPL method provides a practical method for use within a clinical setting. We suggest that DNA methylation of H19 and PEG1 differentially methylated regions (DMRs) may provide novel biomarkers useful for screening, diagnosis and, potentially, for improving the clinical management of women with human ovarian cancer.
\end{abstract}

Keywords: Genomic imprinting, Ovarian cancer, DNA methylation, Bisulphite PCR-Luminex(BPL)method, LOI (loss of imprinting)

\section{Background}

Human ovarian cancer (HOC) is the leading cause of death from gynecological malignancies, primarily due to the lateness of detection when the cancer is already at an advanced stage. Effective screening protocols for early stages are not currently available. HOC is characterized by complex genetic and epigenetic alterations, including loss of heterozygosity (LOH) and loss of imprinting (LOI) $[1,2]$. Such alterations are presumed to represent the second hit, according to Knudson's two-hit hypothesis (OMIM \#167000) [3]. However, alterations in DNA

\footnotetext{
* Correspondence: tarima@med.tohoku.ac.jp

'Department of Informative Genetics, Environment and Genome Research Center, Tohoku University Graduate School of Medicine, 2-1 Seiryo-cho, Aoba-ku, Sendai 980-8575, Japan

Full list of author information is available at the end of the article
}

methylation can also occur as the first hit during human carcinogenesis [4].

For childhood cancers such as retinoblastoma (OMIM \#180200), Wilms' tumor (OMIM \#194070) and osteosarcoma (OMIM \#259500), changes primarily occur on the paternal allele first, followed by a second hit on the maternal allele [5,6]. Complete hydatidiform moles, which are of androgenetic or paternal origin, are characterized by malignant transformation whereas ovarian teratomas, which are of parthenogenetic or maternal origin, are benign $[7,8]$. These observations suggest a role for altered genomic imprinting in the malignant transformation process.

Alterations in the expression of imprinted genes represent one of the most common changes seen in cancer $[9,10]$. Some imprinted genes, including H19

\section{Biomed Central}


[11], GTL2 [12], PEG1, PEG3 [13], LIT1 (KCNQ1OT1) [14] and $Z A C$ [15], are known to act, or strongly implicated to act, as tumor suppressor genes (TSGs). The monoallelic expression of imprinted genes is reliant on epigenetic mechanisms, most notably DNA methylation, which initiates the imprinting process in the male and female germlines at discrete locations termed differentially methylated regions (DMRs) [16]. Imprinted domains generally contain several genes displaying allele-specific expression and these DMRs, which can be located over the promoter of a protein coding gene or the promoter of a functional non-coding RNA or within intergenic regions, are known to control imprinted gene expression within the domain, acting as imprinting centers or imprint control regions [17]. We recently developed a new high-throughput, high-resolution DNA methylation analysis method called bisulphite PCR-Luminex (BPL) for the rapid analysis of DNA methylation [18]. In this study, we applied this method to $21 \mathrm{HOC}$ cell lines and 74 HOC tissues to efficiently and accurately determine the methylation status of DMRs at eight imprinted loci, six of which contained TSGs. To determine whether abnormal methylation of these DMRs acts as an indicator for potential $\mathrm{LOH}$ and/or LOI, we also examined the association between abnormal hypermethylation and LOI or LOH. We found a higher frequency of LOI than LOH. LOI at IGF2, PEG1 and H19 was a frequent alteration, with a tendency to show a more hypermethylated status. The degrees of LOI and altered DNA methylation were similar among histology, progression and tumor grades. This suggests that DNA methylation of the H19 and PEG1 DMRs may provide novel biomarkers useful for screening, diagnosis and, potentially, for improving the clinical management of women with HOC.

\section{Results}

\section{Frequencies of the 8 imprinted gene profiles in HOC}

We first determined whether the ovarian malignancies showed $\mathrm{LOH}$ by comparing the restriction fragment length polymorphism (RFLP) patterns of normal lymphocyte DNA and 74 matching primary HOC DNA samples. Samples where RFLPs were present in the lymphocyte DNA sample but absent or with an altered ratio in the tumor sample were considered to exhibit $\mathrm{LOH}$ in the regions of 8 imprinted genes (H19, IGF2, KCNQ1, LIT1, GTL2, PEG1, PEG3 and NDN). The average percentage of heterozygosity was $48.0 \%$ (16.2-58.5\%). We found only 14 cases of LOH in the 8 imprinted genes in the $74 \mathrm{HOC}$ samples we analysed (Table 1). The most frequent gene with LOH was IGF2 $(9.0 \%, 3 / 33)$, followed by PEG1 $(8.1 \%$, $3 / 37)$ and GTL2 (7.1\%, 3/42). LOH of NDN and LOT1 was not detected $(0 / 31$ and $0 / 12)$. The samples with $\mathrm{LOH}$ were not from the same cases (Additional file 1: Table 1).
We next performed RT-PCR and RFLP analysis to identify the samples of LOI without LOH. The frequency of LOI was higher than that of $\mathrm{LOH}$ for all 8 imprinted genes and we found a total of 46 cases of LOI (Table 1 , Additional file 1: Table S1). The most frequent sites of LOI were PEG1 (45.9\%, 17/37), IGF2 (45.4\%, 15/33) and $H 19(29.2 \%, 12 / 41)$. NDN had the lowest frequency. In 19 of the 46 cases, the abnormal gene expression pattern was apparent at two or more imprinted loci. A normal imprinting pattern, maintenance of imprint (MOI), was most frequent in $N D N(93.5 \%, 29 / 31)$. ND (not determined) means no amplification of RT-PCR at 3 times in several samples, perhaps indicating low expression of the genes. In 9 of the $14 \mathrm{LOH}$ cases, LOI was also found in at least one gene. In HOC cell lines, LOI was found in 2 of 3 informative cases for IGF2, and 3 of 9 cases for PEG1. We did not find any LOH or LOI in 7 normal ovarian surface tissues and 4 normal cell lines. We compared patients' ages, progression, histology and tumor grades with imprinted gene expression pattern profiles. Patients with LOI had a tendency to be younger than patients with $\mathrm{LOH}$ (mean ages for LOH and LOI: $55.0 \pm 7.4$ and $47.7 \pm$ 6.9 , respectively), but the difference was not statistically significant by ANOVA, and no other correlations were apparent.

\section{Analysis of the methylation status of DMRs in ovarian cancers by the BPL method}

The proof-of principle experiment of the BPL method has been described in detail [18]. Briefly, bisulphite-DNA can be used to distinguish between methylation and nonmethylation status in the genome, e.g. cytosine and uracil. The BPL method can determine one base substitution by specific hybridization and detect the ratio of methylation to non-methylation. We examined the quality of the BPL method in spermatic DNA, which should show 100\% methylation of the paternally methylated DMRs: ZDBF2, $H 19$ and GTL2, whereas the maternally methylated DMRs: PEG1, ZAC, SNRPN, PEG3 and LIT1 are non-methylated. We applied the classic methylation assay COBRA technique and our recently devised BPL method to the DNA of 7 normal ovarian surface epithelium tissues, 4 primary cultures of normal human ovarian surface epithelium (OSE1-4) and 21 HOC cell lines, and performed statistical analysis with Spearman's and Pearson's rank correlations. For all 8 DMRs a good correlation was found between these two methods (Figure 1, Table 2, Additional file 2: Figure S1).

We next determined the methylation status of the 8 DMRs from the 74 samples of primary ovarian cancer tissue by the BPL method. Overall, we compared the average DNA methylation status of cancer and normal samples for each DMR and found that PEG1 from ovarian cancers was 
Table 1 Frequencies of LOH, LOI and MOI in human ovarian cancers.

\begin{tabular}{|c|c|c|c|c|c|c|c|c|}
\hline \multicolumn{9}{|c|}{ (A) Ovarian cancer tissues } \\
\hline & $\begin{array}{l}\mathrm{H} 19 / \\
\mathrm{R} \text { sal }\end{array}$ & $\begin{array}{l}\text { IGF2/ } \\
\text { Apal }\end{array}$ & $\begin{array}{l}\text { KCNQ1/ } \\
\text { Smal }\end{array}$ & $\begin{array}{l}\text { LIT1/ } \\
\text { R sal }\end{array}$ & $\begin{array}{l}\text { GTL2/ } \\
\text { T aal }\end{array}$ & $\begin{array}{l}\text { PEG1/ } \\
\text { AFIII }\end{array}$ & $\begin{array}{l}\text { PEG3/ } \\
\text { Mnll }\end{array}$ & $\begin{array}{l}\text { NDN/ } \\
\text { Mbol }\end{array}$ \\
\hline Heterozygosity & $\begin{array}{l}58.5 \\
(41 / 70)\end{array}$ & $\begin{array}{l}47.1 \\
(33 / 70)\end{array}$ & $\begin{array}{l}55.5 \\
(40 / 72)\end{array}$ & $\begin{array}{l}16.2 \\
(12 / 74)\end{array}$ & $\begin{array}{l}58.3 \\
(42 / 72)\end{array}$ & $\begin{array}{l}50.0 \\
(37 / 74)\end{array}$ & $\begin{array}{l}34.2 \\
(25 / 73)\end{array}$ & $\begin{array}{l}41.8 \\
(31 / 74)\end{array}$ \\
\hline $\mathrm{LOH}$ & $\begin{array}{l}4.8 \\
(2 / 41)\end{array}$ & $\begin{array}{l}9.0 \\
(3 / 33)\end{array}$ & $\begin{array}{l}5.0 \\
(2 / 40)\end{array}$ & $\begin{array}{l}0.0 \\
(0 / 12)\end{array}$ & $\begin{array}{l}7.1 \\
(3 / 42)\end{array}$ & $\begin{array}{l}8.1 \\
(3 / 37)\end{array}$ & $\begin{array}{l}4.0 \\
(1 / 25)\end{array}$ & $\begin{array}{l}0.0 \\
(0 / 31)\end{array}$ \\
\hline LOI & $\begin{array}{l}29.2 \\
(12 / 41)\end{array}$ & $\begin{array}{l}45.4 \\
(15 / 33)\end{array}$ & $\begin{array}{l}12.5 \\
(5 / 40)\end{array}$ & $\begin{array}{l}16.6 \\
(2 / 12)\end{array}$ & $\begin{array}{l}23.8 \\
(10 / 42)\end{array}$ & $\begin{array}{l}45.9 \\
(17 / 37)\end{array}$ & $\begin{array}{l}8.0 \\
(2 / 25)\end{array}$ & $\begin{array}{l}6.4 \\
(2 / 31)\end{array}$ \\
\hline $\mathrm{MOI}$ & $\begin{array}{l}56.0 \\
(23 / 41)\end{array}$ & $\begin{array}{l}33.3 \\
(11 / 33)\end{array}$ & $\begin{array}{l}77.5 \\
(31 / 40)\end{array}$ & $\begin{array}{l}83.3 \\
(10 / 12)\end{array}$ & $\begin{array}{l}66.6 \\
(28 / 42)\end{array}$ & $\begin{array}{l}45.9 \\
(17 / 37)\end{array}$ & $\begin{array}{l}84.0 \\
(21 / 25)\end{array}$ & $\begin{array}{l}93.5 \\
(29 / 31)\end{array}$ \\
\hline ND & $\begin{array}{l}9.7 \\
(4 / 41)\end{array}$ & $\begin{array}{l}12.1 \\
(4 / 33)\end{array}$ & $\begin{array}{l}5.0 \\
(2 / 40)\end{array}$ & $\begin{array}{l}0.0 \\
(0 / 12)\end{array}$ & $\begin{array}{l}2.3 \\
(1 / 42)\end{array}$ & $\begin{array}{l}0.0 \\
(0 / 37)\end{array}$ & $\begin{array}{l}4.0 \\
(1 / 25)\end{array}$ & $\begin{array}{l}0.0 \\
(0 / 31)\end{array}$ \\
\hline \multicolumn{9}{|l|}{ (B) Cell lines } \\
\hline Heterozygosity & $\begin{array}{l}19.0 \\
(4 / 21)\end{array}$ & $\begin{array}{l}14.2 \\
(3 / 21)\end{array}$ & $\begin{array}{l}33.3 \\
(7 / 21)\end{array}$ & $\begin{array}{l}14.39 \\
(3 / 21)\end{array}$ & $\begin{array}{l}23.8 \\
(5 / 21)\end{array}$ & $\begin{array}{l}42.8 \\
(9 / 21)\end{array}$ & $\begin{array}{l}23.8 \\
(5 / 21)\end{array}$ & $\begin{array}{l}23.8 \\
(5 / 21)\end{array}$ \\
\hline LOI & $0 / 4$ & $2 / 3$ & $3 / 7$ & $1 / 3$ & $2 / 5$ & $3 / 9$ & $0 / 5$ & $0 / 5$ \\
\hline $\mathrm{MOI}$ & $4 / 4$ & $1 / 3$ & $4 / 7$ & $2 / 3$ & $3 / 5$ & $6 / 9$ & $5 / 5$ & $5 / 5$ \\
\hline
\end{tabular}

Percents of LOH (loss of heterozygosity), LOI (loss of imprinting) and MOI (maintenance of methylation) determined using RFLP analysis of 8 imprinted genes in 74 samples of ovarian cancers and 21 cell lines

significantly more hypermethylated than normal ovarian tissues (normal, 30.7\% \pm 15.1: HOC, $45.9 \% \pm 15.5$ ) (Table 3). The numbers of cancer tissue cases with hypermethylation above the range of the methylation rates in the normal ovarian surface epithelium were 17 for H19, 21 for GTL2, 21 for ZDBF2, and 14 for PEG1 (Table 3). On the other hand, hypomethylation below the methylation level of normal ovarian tissues was found in 15 cases for GTL2 and 23 for ZDBF2. We did not observe a significant difference in the DNA methylation between localized early-stage and advanced-stage tumor groups (Table 3). This suggested that the DNA methylation changes we detected occurred as early events of ovarian cancer.

The association between DNA methylation status and LOH/LOI in ovarian cancers

To determine whether the DNA methylation status in these DMRs of the imprinted genes acts as an indicator for potential $\mathrm{LOH}$ and/or LOI, we evaluated the




Table 2 The methylation profiles of 8 imprinted genes by bisulphite PCR Luminex.

\begin{tabular}{|c|c|c|c|c|c|c|c|c|c|c|c|c|c|c|c|c|c|}
\hline \multirow{3}{*}{$\begin{array}{l}\text { Cell } \\
\text { lines }\end{array}$} & \multirow[t]{3}{*}{ Histology } & \multicolumn{2}{|c|}{$\mathrm{H} 19$} & \multicolumn{2}{|c|}{ GTL2 } & \multicolumn{2}{|c|}{ ZDBF2 } & \multicolumn{2}{|c|}{ PEG1 } & \multicolumn{2}{|c|}{ LIT1 } & \multicolumn{2}{|c|}{ ZAC } & \multicolumn{2}{|c|}{ PEG3 } & \multicolumn{2}{|c|}{ SNRPN } \\
\hline & & BPL & COBRA & BPL & COBRA & BPL & COBRA & BPL & COBRA & BPL & COBRA & BPL & COBRA & BPL & COBRA & BPL & COBRA \\
\hline & & $\begin{array}{l}\text { CpG } \\
(9,16)\end{array}$ & CpG10 & $\begin{array}{l}\text { CpG } \\
(4,8)\end{array}$ & CpG8 & $\begin{array}{c}\text { CpG } \\
(1,4,5)\end{array}$ & CpG4 & CpG15 & CpG12 & $\begin{array}{c}\text { CpG } \\
(5,17,19)\end{array}$ & CpG16 & CpG8 & CpG7 & CpG20 & CpG21 & CpG19 & CpG19 \\
\hline $\mathrm{NC1}$ & $\mathrm{N}$ & 67.5 & 34.6 & 62.2 & 76.8 & 66.4 & 46.2 & 50.4 & 38.5 & 42.7 & 27.4 & 62.3 & 48.4 & 78.8 & 67.4 & 65.3 & 57.3 \\
\hline NC2 & $\mathrm{N}$ & 55.6 & 42.7 & 67.3 & 82.1 & 67.9 & 72.5 & 54.8 & 46.2 & 53.7 & 37.5 & 65.2 & 69.3 & 65.4 & 48.9 & 78.5 & 67.3 \\
\hline NC3 & $N$ & 65.8 & 58.3 & 81.2 & 63.5 & 76.3 & 82.1 & 45.3 & 63.9 & 26.4 & 41.6 & 50.2 & 72.1 & 65.8 & 83.2 & 56.3 & 68.2 \\
\hline NC4 & $N$ & 58.6 & 72.1 & 76.4 & 80.4 & 80.2 & 67.2 & 37.5 & 58.2 & 35.8 & 54.7 & 47.2 & 52.8 & 45.9 & 58.3 & 65.2 & 74.9 \\
\hline $\mathrm{OC1}$ & S & 10.32 & 95.4 & 69.8 & 53.2 & 87.3 & 92.4 & 83.1 & 59.2 & 64.3 & 48.3 & 89.5 & 98.3 & 74.4 & 83.2 & 65.4 & 58.4 \\
\hline $\mathrm{OC2}$ & M & 16.8 & 19.4 & 61.4 & 70.5 & 95.7 & 97.2 & 48.8 & 62.2 & 62.1 & 48.0 & 20.1 & 10.2 & 92.1 & 89.5 & 29.1 & 49.7 \\
\hline OC3 & S & 87.4 & 93.2 & 96.3 & 93.4 & 83.7 & 28.6 & 98.3 & 90.4 & 87.4 & 56.9 & 87.3 & 96.5 & 98.5 & 96.4 & 28.4 & 37.4 \\
\hline OC4 & S & 42.8 & 56.8 & 97.3 & 93.2 & 99.3 & 98.5 & 0.9 & 10.4 & 13.2 & 17.1 & 100.9 & 98.3 & 48.7 & 47.2 & 28.1 & 24.2 \\
\hline OC5 & S & 83.4 & 56.4 & 89.2 & 96.6 & 95.3 & 72.8 & 93.2 & 102.4 & 28.4 & 32.6 & 100.3 & 91.3 & 98.8 & 95.6 & 54.3 & 60.4 \\
\hline OC6 & E & 78.9 & 72.1 & 94.3 & 82.1 & 38.3 & 18.3 & 83.2 & 68.5 & 34.2 & 56.2 & 85.3 & 78.9 & 57.2 & 97.5 & 40.5 & 53.1 \\
\hline OC7 & C & 0.4 & 21.3 & 19.8 & 29.3 & 41.7 & 55.5 & 60.5 & 42.0 & 21.2 & 11.3 & 34.5 & 40.1 & 90.7 & 99.0 & 23.5 & 52.8 \\
\hline OC8 & C & 0.1 & 6.9 & 6.4 & 10.5 & 91.7 & 87.3 & 81.8 & 88.1 & 35.2 & 29.1 & 49.8 & 53.2 & 102.1 & 95.7 & 21.8 & 33.2 \\
\hline OC9 & S & 82.3 & 54.3 & 37.4 & 65.2 & 22.4 & 42.8 & 23.6 & 18.5 & 43.7 & 56.8 & 69.5 & 74.9 & 68.5 & 90.2 & 38.2 & 56.3 \\
\hline OC10 & C & 83.8 & 67.8 & 78.4 & 65.9 & 27.9 & 32.3 & 63.8 & 58.7 & 42.8 & 60.2 & 89.9 & 93.7 & 59.6 & 43.9 & 38.9 & 71.4 \\
\hline OC11 & S & 92.4 & 91.6 & 17.1 & 25.0 & 6.0 & 18.0 & 43.2 & 60.1 & 18.2 & 10.0 & 72.5 & 58.2 & 101.4 & 100.0 & 75.5 & 60.5 \\
\hline OC12 & S & 54.7 & 53.8 & 23.7 & 18.8 & 48.6 & 74.3 & 68.9 & 58.4 & 48.3 & 93.6 & 98.8 & 67.4 & 39.8 & 73.4 & 57.1 & 51.2 \\
\hline OC13 & S & 80.3 & 66.2 & 42.3 & 40.1 & 86.0 & 74.2 & 93.4 & 95.2 & 10.5 & 8.8 & 94.4 & 90.5 & 102.1 & 100.0 & 36.0 & 39.5 \\
\hline OC14 & C & 98.1 & 87.7 & 67.4 & 40.3 & 99.3 & 90.2 & 99.6 & 95.5 & 12.3 & 1.6 & 34.3 & 41.2 & 92.1 & 100.0 & 38.1 & 51.2 \\
\hline OC15 & C & 45.2 & 45.0 & 93.0 & 98.2 & 99.7 & 95.3 & 92.1 & 94.8 & 55.0 & 47.5 & 27.5 & 36.4 & 86.1 & 97.2 & 48.7 & 10.1 \\
\hline OC16 & S & 36.9 & 44.6 & 90.6 & 92.0 & 93.0 & 92.3 & 100.7 & 100.0 & 13.0 & 6.2 & 28.9 & 35.7 & 93.2 & 100.0 & 22.9 & 17.6 \\
\hline OC17 & C & 93.8 & 89.8 & 61.8 & 68.3 & 21.8 & 22.2 & 37.9 & 42.5 & 48.4 & 31.8 & 20.6 & 31.1 & 98.3 & 95.5 & 0.0 & 0.2 \\
\hline OC18 & C & 34.4 & 46.0 & 94.5 & 98.0 & 95.3 & 98.0 & 60.1 & 73.2 & 35.2 & 29.4 & 17.3 & 35.0 & 87.2 & 100.0 & 22.7 & 11.1 \\
\hline OC19 & $C$ & 67 & 30.7 & 47.8 & 62.1 & 87.4 & 85.3 & 4.1 & 10.1 & 11.2 & 0.0 & 100.1 & 100.0 & 84.6 & 92.1 & 30.4 & 31.4 \\
\hline OC20 & M & 1.6 & 42.6 & 58.1 & 60.3 & 62.4 & 55.2 & 73.4 & 81.4 & 18.3 & 13.4 & 49.2 & 68.2 & 92.8 & 98.5 & 86.7 & 44.8 \\
\hline OC21 & $S$ & 8.0 & 24.5 & 80.2 & 87.0 & 96.6 & 90.1 & 77.2 & 81.2 & 4.5 & 8.1 & 100.5 & 97.5 & 107.8 & 98.2 & 16.7 & 16.2 \\
\hline \multicolumn{18}{|c|}{ Normal ovarian surface tissues } \\
\hline NT1 (42) & & 57.5 & 76.2 & 43.4 & 51.2 & 37.2 & 65.4 & 51.4 & 38.6 & 49.1 & 42.3 & 53.3 & 41.2 & 42.1 & 40.2 & 521 & 47.8 \\
\hline NT2 (48) & & 27.6 & 25.0 & 23.6 & 21.6 & 46.1 & 34.5 & 20.9 & 34.4 & 23.1 & 12.2 & 5.1 & 32.3 & 21.3 & 20.6 & 22.1 & 33.3 \\
\hline NT3 (40) & & 61.5 & 31.8 & 49.9 & 60.0 & 50.4 & 45.0 & 31.0 & 42.8 & 17.1 & 10.9 & 48.8 & 29.4 & 21.0 & 33.6 & 24.3 & 34.8 \\
\hline NT4 (38) & & 28.9 & 25.0 & 28.4 & 29.6 & 46.1 & 39.3 & 33.4 & 47.8 & 28.8 & 17.7 & 67.4 & 46.1 & 45.6 & 33.8 & 80.5 & 29.0 \\
\hline NT5 (55) & & 24.2 & 26.9 & 27.2 & 18.5 & 33.2 & 29.0 & 30.9 & 48.1 & 25.1 & 17.6 & 10.7 & 44.5 & 75.5 & 40.0 & 32.3 & 31.3 \\
\hline NT6 (45) & & 25.9 & 22.1 & 32.2 & 20.5 & 46.4 & 62.5 & 60.0 & 40.4 & 24.1 & 17.3 & 25.2 & 23.4 & 44.2 & 69.0 & 77.4 & 40.9 \\
\hline NT7 (41) & & 34.6 & 24.6 & 38.0 & 19.9 & 49.9 & 37.4 & 27.3 & 46.2 & 27.7 & 24.5 & 21.0 & 63.1 & 49.7 & 53.7 & 25.6 & 24.5 \\
\hline
\end{tabular}

Letters in blue and black boldface represent $\mathrm{LOH}, \mathrm{LO}$ and MOI, respectively. The Luminex value indicates the average value of DNA methylation 
Table 3 Characterization of methylation profiles of the imprinted genes in DNA of ovarian cancers.

\begin{tabular}{|c|c|c|c|c|c|c|c|c|c|}
\hline \multicolumn{10}{|l|}{ (A) Histology } \\
\hline & & $\mathrm{H} 19$ & GTL2 & ZDBF2 & PEG1 & LIT1 & ZAC & PEG3 & SNRPN \\
\hline Normal & $(n=7)$ & $34.3 \pm 11.8$ & $34.7 \pm 9.5$ & $44.2 \pm 6.6$ & $30.7 \pm 15.1$ & $27.9 \pm 12.6$ & $33.1 \pm 5.8$ & $42.8 \pm 18.5$ & $44.9 \pm 25.3$ \\
\hline Cancer & $(n=74)$ & $41.7 \pm 17.2$ & $39.6 \pm 18.8$ & $43.8 \pm 6.6$ & $45.9 \pm 15.5^{*}$ & $27.9 \pm 14.1$ & $41.1 \pm 6.4$ & $41.1 \pm 14.1$ & $42.8 \pm 12.9$ \\
\hline Serous & $(n=36)$ & $47.6 \pm 18.9$ & $38.8 \pm 22.0$ & $42.0 \pm 18.5$ & $48.9 \pm 14.7^{*}$ & $28.8 \pm 9.8$ & $42.7 \pm 16.6$ & $40.9 \pm 14.8$ & $39.3 \pm 12.2$ \\
\hline Mucinous & $(\mathrm{n}=9)$ & $36.0 \pm 15.0$ & $35.2 \pm 19.2$ & $36.8 \pm 14.0$ & $47.1 \pm 20.0$ & $34.7 \pm 21.4$ & $42.2 \pm 5.9$ & $31.2 \pm 11.2$ & $42.7 \pm 17.8$ \\
\hline Endometrioid & $(n=10)$ & $37.9 \pm 14.8$ & $30.7 \pm 14.4^{* *}$ & $57.8 \pm 19.8$ & $45.5 \pm 13.7$ & $22.8 \pm 13.0$ & $37.5 \pm 11.5$ & $46.8 \pm 15.9$ & $41.4 \pm 10.8$ \\
\hline Clear & $(n=18)$ & $45.6 \pm 20.2$ & $54.0 \pm 20.1$ & $39.7 \pm 20.8$ & $42.2 \pm 13.8$ & $25.5 \pm 12.4$ & $40.2 \pm 16.1$ & $45.7 \pm 14.5$ & $47.8 \pm 11.1$ \\
\hline \multicolumn{10}{|c|}{ (B) Progress (Staging) } \\
\hline Localized (I, II) & $(n=29)$ & $38.8 \pm 14.9$ & $40.8 \pm 20.4$ & $46.7 \pm 19.4$ & $47.8 \pm 17.1$ & $30.4 \pm 16.1$ & $41.0 \pm 11.9$ & $42.8 \pm 17.8$ & $44.2 \pm 12.9$ \\
\hline Advanced (III, IV) & $(n=45)$ & $47.8 \pm 19.6$ & $41.3 \pm 22.2$ & $41.9 \pm 19.2$ & $45.9 \pm 13.7$ & $26.2 \pm 10.0$ & $41.1 \pm 16.8$ & $41.2 \pm 12.8$ & $40.9 \pm 12.6$ \\
\hline \multicolumn{10}{|l|}{ (C) Age } \\
\hline Under 44 years & $(n=17)$ & $46.7 \pm 18.5$ & $35.3 \pm 21.0$ & $42.0 \pm 20.4$ & $48.9 \pm 13.5$ & $24.2 \pm 11.7$ & $39.9 \pm 12.3$ & $44.7 \pm 14.3$ & $36.3 \pm 10.7$ \\
\hline $45-55$ years & $(n=29)$ & $39.9 \pm 14.7$ & $47.2 \pm 23.0$ & $45.8 \pm 17.5$ & $46.9 \pm 15.0$ & $30.1 \pm 14.8$ & $38.9 \pm 15.5$ & $41.9 \pm 15.8$ & $45.4 \pm 11.1$ \\
\hline Over 56 years & $(n=32)$ & $47.4 \pm 21.2$ & $38.4 \pm 18.1$ & $42.2 \pm 21.1$ & $45.1 \pm 16.2$ & $28.2 \pm 10.9$ & $44.1 \pm 15.7$ & $40.8 \pm 14.9$ & $42.5 \pm 14.5$ \\
\hline
\end{tabular}

The values in the list are mean \pm SD (standard deviation). Statistically significant differences between groups are presented as ${ }^{*} \mathrm{P}<0.05$, and ${ }^{* *} \mathrm{P}<0.01$ by ANOVA

association between DNA methylation and LOH and/or LOI in the IGF2/H19 and PEG1 imprinted domains separately.

IGF2, which acts as a dominant oncogene, and $H 19$, a physically and mechanistically linked gene on human chromosome 11, are reciprocally imprinted. In the paternal allele, $H 19$ DMR is methylated and silenced, whereas the reciprocally imprinted gene IGF2 is transcribed. By contrast, in the maternal unmethylated allele, H19 is expressed but IGF2 is inactivated because of the binding of the repressor factor CTCF to the unmethylated H19
DMR, which then prevents the H19/IGF2 common enhancers from activating the IGF2 promoter [19]. IGF2 was found to have high frequencies of both $\mathrm{LOH}$ and LOI in HOC. H19 was also found to have high frequencies of LOI $(29.2 \%, 12 / 41)$. Nine of 14 cases with both IGF2 and H19 heterozygosity showed LOH or LOI of both genes and only one case had MOI for one of the two. Thus relaxation of IGF2 and H19 imprinting is frequent. In the IGF2/H19 imprinted region, the samples with $\mathrm{LOH}$ and/or LOI at $\mathrm{H} 19$ was more methylated than those with MOI (Figure 2A, Additional file 3: Table S2).




Our results for $H 19$ were similar to a previously reported finding [20]. PEG1 was reported to be a TSG and was also found to have high frequency of LOH/LOI in HOC. We also found that the samples with LOH/LOI at PEG1 were more methylated than those with MOI with statistical significance (Figure 2B, Additional file 3: Table S2).

\section{Discussion}

Alterations in DNA methylation are the most common molecular alterations in human malignancies. Detection of the aberrant DNA methylation associated with cancerrelated genes is a promising approach to improve cancer prevention, diagnosis and treatment options. Bisulphite modification is a prerequisite for most popular techniques aiming at detecting changes in methylation, but has been limited by throughput capacity. In this study, we used a high-throughput methylation detection method to analyze DNA methylation at 8 imprinted DMRs in epithelial ovarian cancer. We found that the PCR-Luminex method precisely quantified the methylation status of specific DNA regions in somatic cells and was also relatively rapid, economical and easy to use.

In the epithelial ovarian cancers, the frequency of LOI was higher than that of $\mathrm{LOH}$. In particular, LOI was most frequent at PEG1, IGF2 and H19 DMRs. The frequency, extent of changes in DNA methylation and loci affected varied considerably among the samples. Generally, we found that DNA methylation at imprinted DMRs was increased in both cell lines and primary material. Importantly, we showed that gain of DNA methylation in the imprinted DMRs was apparent in tumors with LOI, especially at PEG1 and H19. We also found DNA methylation changes in the absence of LOI. In other words, there were changes in DNA methylation at DMRs that were not associated with biallelic gene expression.

When we examined the clinical characteristics of the tumors, we found no significant differences in the frequency of LOI and aberrant DNA methylation between the localized early-stage and advanced-stage tumor groups. This suggested that the changes we identified occurred as a relatively early event of HOC. In general, the PEG1 and H19 DMRs appeared to be particularly prone to errors. This is similar to the previous findings in human sperm from subfertile men [21]. In ZDBF2 and GTL2 DMRs, aberrant DNA methylation occurred in HOC. As with H19, these DMRs are paternally methylated DMRs in somatic cells. In childhood cancers such as retinoblastoma, Wilms' tumor and osteosarcoma, changes primarily occur on the paternal allele first, followed by a second hit on the maternal allele $[5,6,22]$. Similarly, methylation of paternally imprinted DMR in normal somatic cells might be a first hit and cause ovarian carcinogenesis. These observations suggest a role for altered genomic imprinting in the malignant transformation process.
A previous report had demonstrated the association between the abnormal genomic imprinting of $H 19$ and IGF2 expression [20]. The aberrant hypermethylation in the CTCF binding site of the $H 19$ gene was seen in the cases of HOC and correlated with IGF2 LOI. Our results for $H 19$ were similar to those reported findings. The most frequent methylation error in HOC was seen in the PEG1 DMR. In our previous report, we showed that demethylation of PEG1 was present in growing oocytes from superovulated infertile women [23]. This PEG1 DMR may be especially vulnerable to errors. LOI of PEG1 has subsequently also been implicated in the aetiology of lung adenocarcinomas, breast and colon cancer.

$\mathrm{HOC}$ is the leading cause of death from gynecologic malignancies because the majority of cases are not detected until the disease is well advanced. Our understanding of cancer as a clonal genetic disease has led to the identification of genetic alterations in many cancer types. However, ovarian cancer remains less well characterized. Only a few TSG genes acting in a recessive manner have been identified as somatically mutated or methylated in ovarian cancer, including TP53 (48\%) [24], PTEN (21\% in the endometrioid subtype) [25], RB1 (7$10 \%$ ) [26], and CDKN2A (79\% in the mucinous subtype) [27]. Biomarkers provide useful tools in screening for cancer and are now emerging as highly informative for monitoring disease status [28]. They can improve early detection and also the quality of life of patients with ovarian cancer. DNA methylation offers an additional tool that can be used in combination with other markers [29]. In addition, it has been established that DNA methylation biomarkers are present in patient serum and other body fluids [30]. To date, several methylated genes have been found to be highly prognostic for specific cancers, including those of the prostate [31], breast [32] and lung [33]. Although some methylated markers such as RASSF1A and GSTP1 have potential as prognostic indicators individually [34,35], 'methylation signature' panels could be much more informative [36] and accurate for monitoring cancer progression. Methylation patterns have previously been suggested to be tumor and stage specific [37]. Our work demonstrates that there is aberrant DNA methylation at several imprinted DMRs in HOC with changes at PEG1 and $H 19$ being the most frequent and earliest alterations detected.

\section{Conclusion}

This is the first study reporting the use of PCR-Luminex for identification of prognostic panels of DNA methylation biomarkers for cancer. We believe that this approach is amenable to the classification of clinically relevant methylation patterns in a wide variety of tumors (and other pathologies) linked to the aberrant DNA methylation of imprinted DMRs. This BPL method may be sufficiently 
sensitive that it can be applied to the analysis of DNA methylation in the very small number of circulating cancer cells found in blood and urine samples from patients.

\section{Methods \\ Ovarian cancer cell lines and primary culture of surface epithelial cells}

Twenty-one HOC cell lines were used in our study: 10 from serous adenocarcinoma (OVCAR3, CAOV3, JHOS2, HTOA, SKOV3, OV90, JHOS3, JHOS4, KF, MH), 2 from mucinous adenocarcinoma (OMC3, MCAS), 8 from clear cell adenocarcinoma (ES2, JHOC5, TOV21G, JHOC7, JHOC8, KM, HAC2, RMG) and 1 from endometrioid adenocarcinoma (TOV112D). The sources of these cells and culture methods were as described previously [38,39]. Four primary cultures of normal human ovarian surface epithelial (OSE1-4) cells were initiated from surface scrapings of normal ovaries as described [40].

\section{Ovarian cancer tissue(s)}

Seventy-four primary HOC tissues (36 serous, 9 mucinous, 10 endometrioid, 18 clear cell, and 1 other, Table 3) were obtained from patients presenting at our hospital. The mean \pm standard deviation (SD) of the patients' ages for normal ovary and ovarian cancer tissues were 44.1 \pm 6.6 and $52.9 \pm 7.3$, respectively. Seven specimens of normal ovarian surface epithelium were obtained from patients with benign non-ovarian disease. Histological diagnoses and clinical staging were performed according to the International Federation of Gynecologists and Obstetricians (FIGO) criteria. The numbers of cancer patients with localized tumors (stage I and II) and advanced tumor (stages III and IV) were 29 and 45, respectively. The samples were stained with hematoxylin and eosin to demonstrate $>85 \%$ of epithelial tumor cells. DNA and RNA were then extracted from the remaining samples [38]. DNA was also extracted from peripheral blood in matched patients. The study was performed after obtaining the patients' informed consent and with approval from the institutional ethics committee of the Tohoku University Graduate School of Medicine.

\section{Analysis of loss of heterozygosity (LOH) and loss of imprinting (LOI)}

PCR was performed on patient blood and tumor genomic DNA using the primer sequences summarized in Additional file 4: Table S3. A PCR reaction mix containing $0.5 \mu \mathrm{M}$ of each primer set, $200 \mu \mathrm{M}$ dNTPs, $1 \times$ PCR buffer, and 1.25U of EX Taq Hot Start DNA Polymerase (Takara Bio, Tokyo, Japan) in a total volume of $20 \mu \mathrm{l}$ was used. The following PCR program was used: 1 minute of denaturation at $94^{\circ} \mathrm{C}$ followed by 35 cycles of 30 seconds at $94^{\circ} \mathrm{C}, 30$ seconds at $60^{\circ} \mathrm{C}$ and 30 seconds at $72^{\circ} \mathrm{C}$ and a final extension for 5 minutes at $72^{\circ} \mathrm{C}$. PCR products were digested by unique polymorphic enzymes to identify samples that were heterozygous for a single nucleotide polymorphism (SNP). For samples found to be heterozygous for a SNP, RNA was prepared from matched tumors, followed by reverse transcription-PCR (RT-PCR) and by restriction digestion [41-48]. The digested PCR products were electrophoresed on $2 \%$ agarose gel.

\section{DNA methylation analysis}

Bisulphite PCR-Luminex (BPL) methylation analysis was performed as described [18]. PCR primers sets, biotinylated at their 5'-end, were designed for gene amplification. PCR reaction mix contained $0.2 \mu \mathrm{M}$ primer, $0.2 \mathrm{mM}$ dNTPs, $1 \times$ PCR buffer $(50 \mathrm{mM} \mathrm{KCl}, 10 \mathrm{mM}$ Tris- $\mathrm{HCl}$, $\mathrm{pH}$ 8.3). $3 \mathrm{mM} \mathrm{MgCl} 2,2 \%$ dimethyl sulfoxide (DMSO), 0.625U Taq DNA Polymerase (Roche, Tokyo, Japan) and 100-200 ng of bisulphite treated DNA in a total volume of $25 \mu \mathrm{l}$. PCR conditions: 40 cycles of $95^{\circ} \mathrm{C}$ for $20 \mathrm{~s} / 60^{\circ} \mathrm{C}$ for $30 \mathrm{~s} / 72^{\circ} \mathrm{C}$ for $30 \mathrm{~s}$ using a GeneAmp 9700 thermal cycler (Applied Biosystems, CA, USA). Oligonucleotide probe sequences (Additional file 2: Table S1 in Ref 18) were synthesized and covalently bound to carboxylated fluorescent microbeads using ethylene dichloride (EDC). These oligonucleotide-labeled microbeads (oligobeads) were mixed together to make an oligobeads mixture of 100 oligobeads/ $\mu \mathrm{l}$ and hybridized to the 5 '-biotin-labeled PCR amplicons in a total volume of $50 \mu \mathrm{l}$ per well in a 96-well plate by adding $5 \mu \mathrm{l}$ of the appropriate oligobead mixture and $5 \mu \mathrm{l}$ of the PCR amplicons to $40 \mu \mathrm{l}$ of hybridization buffer. This reaction mixture was first denatured at $95^{\circ} \mathrm{C}$ for $2 \mathrm{~min}$ and then hybridized at $48^{\circ} \mathrm{C}$ for $30 \mathrm{~min}$. After hybridization, the oligobeads were washed in $100 \mu \mathrm{l}$ of PBS-Tween and pelleted by microcentrifugation. Pelleted oligobeads were reacted with a $70 \mu$ l aliquot of a $100 \times$ diluted solution of SA-PE in PBS-Tween. Hybridized amplicons were labeled with SA-PE at $48^{\circ} \mathrm{C}$ for $15 \mathrm{~min}$. Reaction outcomes were measured by the Luminex 100 flow cytometer. Methylation assays were additionally performed for each DMR using the conventional bisulphite treatment PCR methylation assay and combined bisulphite PCR restriction analysis (COBRA) as described previously [21].

\section{Statistical analyses}

Differences between groups were analysed by analysis of variance, followed by Post-hoc, Tukey's HSD test. Statistical analyses were performed using the JMP (v9.0.0, SAS Institute Japan, Tokyo, Japan). Statistically significant differences between groups are presented as $* \mathrm{P}<$ 0.05 , and ${ }^{*} \mathrm{P}<0.01$. Results for BPL and COBRA were compared using Spearman's rank method and Pearson's product-moment correlation coefficients. 


\section{Additional material}

\section{Additional file 1: Table S1 The list of $\mathrm{LOH}$, LOI and MOI in HOC.}

$\mathrm{LOH}, \mathrm{LOI}$ and $\mathrm{MOI}$ determined using RFLP analysis of 8 imprinted genes are summarized. NC: Normal cells (NC1-4). NT: Normal ovarian tissues (NT1-7). CC: Cancer cell lines (CC1-21). CT: Cancer tissue (CT1-74).

\section{Additional file 2: Figure S1 Validation of BPL analyses by} comparison with COBRA assay. Examination of the imprinted DMRs by bisulphite PCR Luminex (BPL) and combined bisulphite PCR restriction analysis (COBRA) assay in DNA samples of ovarian cancer cell lines and normal cells. BPL: $y$-axis, COBRA: $x$-axis. The number was calculated by Spearman's rank method. GTL2 (C), ZDBF2 (D), LIT1 (E), ZAC (F), PEG3 (G) and SNRPN $(\mathrm{H})$

Additional file 3: Table S2 Sequences of PCR primers and restriction enzymes used for PCR-RFLP analysis

Additional file 4: Table S3 Bisulphite PCR-Luminex and COBRA methylation profiles of the eight imprinted DMRs in the DNA of human ovarian cancer cells and normal ovarian tissues. Numbers in blue and black boldface indicate $\mathrm{LOI}$ and $\mathrm{MOI}$, respectively. Luminex values indicate average methylation values at the sites tested. $\mathrm{NC}$ : Normal cells (OSE1, OSE2, OSE3, OSE4). CC: Cancer cell lines (CC1: OVCAR3, CC2: OMC3, CC3: CAOV3, CC4: JHOS2, CC5: HTOA, CC6: TOV112D, CC7: ES2, CC8: JHOC5, CC9: SKOV3, CC10: TOV21G, CC11: OV90, CC12: JHOS3, CC13: JHOS4, CC14: JHOC7, CC15: JHOC8, CC16: KF, CC17: KM, CC18: HAC, CC19: RMG, CC20: MCAS, CC21: MH. NT: Normal ovarian tissues (NT1-NT7). N: Normal, S: Serous adenocarcinoma, M: Mucinous adenocarcinoma, E: Endometrioid carcinoma, C: Clear cell carcinoma.

\section{Abbreviations}

BPL: Bisulphite PCR-Luminex; COBRA: Combined bisulphite PCR restriction analysis; DMR: Differentially methylated region; FIGO: International Federation of Gynecologists and Obstetricians; HOC: Human ovarian cancer; LOH: Loss of heterozygosity; LOI: Loss of imprinting; MOI: Maintenance of imprint; ND: Not determined; PCR: Polymerase chain reaction; QOL: Quality of Life; RFLP: Restriction fragment length polymorphism; RT-PCR: Reverse transcriptionPCR; SNP: Single nucleotide polymorphism.

\section{Acknowledgements}

We would like to thank Yukiko Abe, Takuya Koshizaka (G\&G SCIENCE Co. Ltd., Fukushima Japan) and all the members of our laboratory for technical assistance and their support and valuable suggestions. In particular, we thank Dr. R. M. John for comments on the manuscript. This work was supported by Grant-in-Aid for Scientific Research (KAKENHI) (21028003, 23013003, 23390385), Uehara Memorial Foundation and the Environment Research \& Technology Development Fund (C1008) (TA).

\section{Author details}

'Department of Informative Genetics, Environment and Genome Research Center, Tohoku University Graduate School of Medicine, 2-1 Seiryo-cho, Aoba-ku, Sendai 980-8575, Japan. ${ }^{2}$ Department of BioScience, Tokyo University of Agriculture, 1-1-1 Sakuragaoka, Setagaya-ku, Tokyo 156-8502, Japan. ${ }^{3}$ Departments of Obstetrics and Gynecology, Tohoku University Graduate, School of Medicine, Sendai, Japan. ${ }^{4}$ Department of Development and Environmental Medicine, Tohoku University Graduate School of Medicine, Sendai, Japan.

\section{Authors' contributions}

$\mathrm{HH}, \mathrm{HO}, \mathrm{HK}, \mathrm{NM}, \mathrm{FS}$ and $\mathrm{AS}$ performed the DNA methylation analyses and validation of the BML method. FS, SN, JS, NY carried out the product and culture of cancer cell lines and collect the tumor samples. KN did the statistical analyses. $\mathrm{HH}$ and TA wrote this manuscript. All authors have read and approved the final manuscript.

\section{Competing interests}

The authors declare that they have no competing interests.
Received: 15 December 2011 Accepted: 26 March 2012

Published: 26 March 2012

\section{References}

1. Russo A, Calo V, Bruno L, Rizzo S, Bazan V, Di Fede G: Hereditary ovarian cancer. Crit Rev Oncol Hematol 2009, 69:28-44.

2. Balch C, Fang F, Matei DE, Huang TH, Nephew KP: Minireview: epigenetic changes in ovarian cancer. Endocrinology 2009, 150:4003-4011.

3. Knudson AG: Genetics of human cancer. Annu Rev Genet 1986, 20:231-251.

4. Jones PA, Laird PW: Cancer epigenetics comes of age. Nat Genet 1999, 21:163-167.

5. Dryja TP, Mukai S, Petersen R, Rapaport JM, Walton D, Yandell DW: Parental origin of mutations of the retinoblastoma gene. Nature 1989, 339:556-558.

6. Huff V, Meadows A, Riccardi VM, Strong LC, Saunders GF: Parental origin of de novo constitutional deletions of chromosomal band 11p13. Am J Hum Genet 1990, 47:155-160.

7. Kajii T, Ohama K: Androgenetic origin of hydatidiform mole. Nature 1977, 268:633-634.

8. Mutter GL: Teratoma genetics and stem cells: a review. Obstet Gynecol Sun 1987, 42:661-670.

9. Feinberg AP: DNA methylation, genomic imprinting and cancer. Curr Top Microbiol Immunol 2000, 249:87-99.

10. Joyce JA, Schofield PN: Genomic imprinting and cancer. Mol Pathol 1998, 51:185-190.

11. Feinberg AP: Imprinting of a genomic domain of $11 \mathrm{p} 15$ and loss of imprinting in cancer: an introduction. Cancer Res 1999, 59:1743-1746.

12. Zhang L, Volinia S, Bonome T, Calin GA, Greshock J, Yang N, et al: Genomic and epigenetic alterations deregulate microRNA expression in human epithelial ovarian cancer. Proc Natl Acad Sci USA 2008, 105:7004-7009.

13. Kohda T, Asai A, Kuroiwa Y, Kobayashi S, Aisaka K, Nagashima G, et al: Tumour suppressor activity of human imprinted gene PEG3 in a glioma cell line. Genes Cells 2001, 6:237-247.

14. Nakano S, Murakami K, Meguro M, Soejima H, Higashimoto K, Urano T, et al: Expression profile of LIT1/KCNQ1OT1 and epigenetic status at the KvDMR1 in colorectal cancers. Cancer Sci 2006, 97:1147-1154.

15. Kamikihara $\mathrm{T}$, Arima $\mathrm{T}$, Kato $\mathrm{K}$, Matsuda $\mathrm{T}$, Kato $\mathrm{H}$, Douchi $\mathrm{T}$, et al: Epigenetic silencing of the imprinted gene ZAC by DNA methylation is an early event in the progression of human ovarian cancer. Int $J$ Cancer 2005, 115:690-700

16. Surani MA: Imprinting and the initiation of gene silencing in the germ line. Cell 1998, 93:309-312.

17. Koerner MV, Barlow DP: Genomic imprinting-an epigenetic generegulatory model. Curr Opin Genet Dev 2010, 20:164-170.

18. Sato A, Hiura H, Okae H, Miyauchi N, Abe Y, Utsunomiya T, et al: Assessing loss of imprint methylation in sperm from subfertile men using novel methylation polymerase chain reaction Luminex analysis. Fertil Steril 2011, 95:129-134

19. Reik W, Walter J: Genomic imprinting: parental influence on the genome. Nat Rev Genet 2001, 2:21-32.

20. Murphy SK, Huang Z, Wen Y, Spillman MA, Whitaker RS, Simel LR, et al: Frequent IGF2/H19 domain epigenetic alterations and elevated IGF2 expression in epithelial ovarian cancer. Molecular cancer research: MCR 2006, 4:283-292.

21. Kobayashi H, Sato A, Otsu E, Hiura H, Tomatsu C, Utsunomiya T, et al: Aberrant DNA methylation of imprinted loci in sperm from oligospermic patients. Hum Mol Genet 2007, 16:2542-2551.

22. Toguchida J, Ishizaki K, Sasaki MS, Nakamura Y, Ikenaga M, Kato M, et al: Preferential mutation of paternally derived RB gene as the initial event in sporadic osteosarcoma. Nature 1989, 338:156-158.

23. Sato A, Otsu E, Negishi H, Utsunomiya T, Arima T: Aberrant DNA methylation of imprinted loci in superovulated oocytes. Hum Reprod 2007, 22:26-35.

24. Olivier $M$, Eeles $R$, Hollstein $M$, Khan MA, Harris CC, Hainaut P: The IARC TP53 database: new online mutation analysis and recommendations to users. Hum Mutat 2002, 19:607-614.

25. Obata K, Morland SJ, Watson RH, Hitchcock A, Chenevix-Trench G, Thomas EJ, et al: Frequent PTEN/MMAC mutations in endometrioid but not serous or mucinous epithelial ovarian tumors. Cancer Res 1998, 58:2095-2097. 
26. Gorringe KL, Jacobs S, Thompson ER, Sridhar A, Qiu W, Choong DY, et al: High-resolution single nucleotide polymorphism array analysis of epithelial ovarian cancer reveals numerous microdeletions and amplifications. Clin Cancer Res 2007, 13:4731-4739.

27. Milde-Langosch K, Ocon E, Becker G, Loning T: p16/MTS1 inactivation in ovarian carcinomas: high frequency of reduced protein expression associated with hyper-methylation or mutation in endometrioid and mucinous tumors. Int J Cancer 1998, 79:61-65.

28. Ludwig JA, Weinstein JN: Biomarkers in cancer staging, prognosis and treatment selection. Nat Rev Cancer 2005, 5:845-856.

29. Ushijima T: Detection and interpretation of altered methylation patterns in cancer cells. Nat Rev Cancer 2005, 5:223-231.

30. Cottrell SE, Laird PW: Sensitive detection of DNA methylation. Ann N Y Acad Sci 2003, 983:120-130.

31. Li LC, Carroll PR, Dahiya R: Epigenetic changes in prostate cancer: implication for diagnosis and treatment. J Natl Cancer Inst 2005, 97:103-115.

32. Bae YK, Brown A, Garrett E, Bornman D, Fackler MJ, Sukumar S, et al: Hypermethylation in histologically distinct classes of breast cancer. Clin Cancer Res 2004, 10:5998-6005.

33. Zochbauer-Muller S, Minna JD, Gazdar AF: Aberrant DNA methylation in lung cancer: biological and clinical implications. Oncologist 2002, 7:451-457.

34. Henrique $\mathrm{R}$, Jeronimo C: Molecular detection of prostate cancer: a role for GSTP1 hypermethylation. Eur Urol 2004, 46:660-669.

35. Yang $Q$, Zage P, Kagan D, Tian Y, Seshadri R, Salwen HR, et al: Association of epigenetic inactivation of RASSF1A with poor outcome in human neuroblastoma. Clin Cancer Res 2004, 10:8493-8500.

36. Esteller M, Corn PG, Baylin SB, Herman JG: A gene hypermethylation profile of human cancer. Cancer Res 2001, 61:3225-3229.

37. Costello JF, Fruhwald MC, Smiraglia DJ, Rush L, Robertson GP, Gao X, et al: Aberrant CpG-island methylation has non-random and tumour-typespecific patterns. Nat Genet 2000, 24:132-138.

38. Suzuki F, Akahira J, Miura I, Suzuki T, Ito K, Hayashi S, et al: Loss of estrogen receptor beta isoform expression and its correlation with aberrant DNA methylation of the $5^{\prime}$-untranslated region in human epithelial ovarian carcinoma. Cancer Sci 2008, 99:2365-2372.

39. Ueoka Y, Kato K, Kuriaki Y, Horiuchi S, Terao Y, Nishida J, et al: Hepatocyte growth factor modulates motility and invasiveness of ovarian carcinomas via Ras-mediated pathway. Br J Cancer 2000, 82:891-899.

40. Kikuchi R, Tsuda H, Kanai Y, Kasamatsu T, Sengoku K, Hirohashi S, et al: Promoter hypermethylation contributes to frequent inactivation of a putative conditional tumor suppressor gene connective tissue growth factor in ovarian cancer. Cancer Res 2007, 67:7095-7105.

41. Vambergue A, Fajardy I, Dufour P, Valat AS, Vandersippe M, Fontaine $P$, et al: No loss of genomic imprinting of IGF-II and H19 in placentas of diabetic pregnancies with fetal macrosomia. Growth Horm IGF Res 2007, 17:130-136.

42. Wylie AA, Murphy SK, Orton TC, Jirtle RL: Novel imprinted DLK1/GTL2 domain on human chromosome 14 contains motifs that mimic those implicated in IGF2/H19 regulation. Genome Res 2000, 10:1711-1718.

43. Ogawa O, Eccles MR, Szeto J, McNoe LA, Yun K, Maw MA, et al: Relaxation of insulin-like growth factor II gene imprinting implicated in Wilms' tumour. Nature 1993, 362:749-751.

44. Maegawa S, Yoshioka H, Itaba N, Kubota N, Nishihara S, Shirayoshi Y, et al: Epigenetic silencing of PEG3 gene expression in human glioma cell lines. Mol Carcinog 2001, 31:1-9.

45. Pedersen IS, Dervan PA, Broderick D, Harrison M, Miller N, Delany E, et al: Frequent loss of imprinting of PEG1/MEST in invasive breast cancer. Cancer Res 1999, 59:5449-5451.

46. Higashimoto K, Soejima H, Yatsuki H, Katsuki T, Mukai T: An Nsil RFLP in the human long QT intronic transcript 1 (LIT1). J Hum Genet 2000, 45:96-97.

47. Mitsuya K, Meguro M, Lee MP, Katoh M, Schulz TC, Kugoh H, et al: An imprinted antisense RNA in the human KvLQT1 locus identified by screening for differentially expressed transcripts using monochromosomal hybrids. Hum Mol Genet 1999, 8:1209-1217.

48. MacDonald HR, Wevrick R: The necdin gene is deleted in Prader-Willi syndrome and is imprinted in human and mouse. Hum Mol Genet 1997, 6:1873-1878

\section{Pre-publication history}

The pre-publication history for this paper can be accessed here: http://www.biomedcentral.com/1755-8794/5/8/prepub

\section{doi:10.1186/1755-8794-5-8}

Cite this article as: Hiura et al:: High-throughput detection of aberrant imprint methylation in the ovarian cancer by the bisulphite PCR-

Luminex method. BMC Medical Genomics 2012 5:8.

\section{Submit your next manuscript to BioMed Central and take full advantage of:}

- Convenient online submission

- Thorough peer review

- No space constraints or color figure charges

- Immediate publication on acceptance

- Inclusion in PubMed, CAS, Scopus and Google Scholar

- Research which is freely available for redistribution

Submit your manuscript at www.biomedcentral.com/submit
Biomed Central 